\title{
23. DISSOLVED ORGANIC CARBON IN INTERSTITIAL WATERS FROM SEDIMENTS OF MIDDLE VALLEY, LEG 1391
}

\author{
Baiyun Ran ${ }^{2}$ and Bernd R.T. Simoneit ${ }^{2}$
}

\begin{abstract}
High-temperature combustion oxidation measurements of nonvolatile dissolved organic carbon (DOC) have been determined for pore waters from sediments of Middle Valley, Ocean Drilling Program Leg 139, as well as for overlying and near-bottom seawater. The DOC values in the interstitial waters are generally greater than those in the overlying water column, ranging from 0.1 to $86 \mathrm{mg} / \mathrm{L}$ of carbon. Some of the profiles of DOC in the pore waters are similar to total organic carbon, total carbon, and total inorganic carbon profiles. At Site 855 the concentrations of DOC in interstitial waters generally decrease with depth. DOC maxima at shallow depths of Site 858 are probably enriched due to higher temperature alteration of organic matter. At Sites 856 and 857 , besides the decreasing trend above, the DOC increases at greater depths, also due to the hydrothermal activity. The values of DOC correlate with $\mathrm{MnO}$ and $\mathrm{MgO}$ profiles in Hole 856B. The changes below $30 \mathrm{mbsf}$ in the DOC depth profiles of Site 858 parallel those of the volatile hydrocarbon gases.
\end{abstract}

\section{INTRODUCTION}

Middle Valley, a northern segment of the Juan de Fuca Ridge, is part of a sedimented seafloor spreading center, where new oceanic crust is created. During Ocean Drilling Program (ODP) Leg 139, multiple holes were drilled within $5 \mathrm{~km}$ of each other in four distinct hydrologic environments in the Middle Valley rift (Fig. 1) (Davis, Mottl, Fisher, et al., 1992). All sediments recovered are of Pleistocene to Holocene age.

Site 855 is situated along the bounding fault on the eastern edge of the rift, in an area of fluid recharge where cold seawater is being drawn down and cooling the hot formations of the hydrothermal system. Evidence that seawater is moving along the fault was found in the low temperature measured in sediments above the fault and in the pore water from the sediments just above the fault, the chemical composition of which is similar to that of seawater. Heat flow at Site 855 is lower than at the other Middle Valley drill sites. The sediment geochemistry from this site represents an "unaltered background" with which chemical alteration of sediments at other drill sites can be compared (Davis, Mottl, Fisher, et al., 1992).

Site 856 is situated over a small hill that has been hydrothermally active in the past. The lithology at this site consists of turbidite, coarse clastic layers of massive sulfide interbedded with silt to fine sand turbidites, and massive sulfide. At Site 856 , about $3 \mathrm{~km}$ west from the fault scarp at Site 855 , relict fluid discharge has created a massive sulfide deposit. This deposit was created when hot fluids containing dissolved metals precipitated sulfides near the seafloor. There is at present no heat flow anomaly associated with this area (Davis, Mottl, Fisher, et al., 1992), but there is one associated with a site of active venting $300 \mathrm{~m}$ south of the sulfide deposit.

The igneous crust is well sealed by the sediments at Site 857 , which are about $500 \mathrm{~m}$ thick and overlie several hundred meters of heavily altered and fractured interlayered sediments and sills (Davis, Mottl, Fisher, et al., 1992). Fluids at temperatures up to $300^{\circ} \mathrm{C}$ were encountered within these rocks.

Site 858 is located about $1.6 \mathrm{~km}$ north of Site 857 in a hydrothermal upflow zone, where hot water discharges into the overlying ocean. Measurements revealed temperatures close to $200^{\circ} \mathrm{C}$ at just 20

\footnotetext{
${ }^{1}$ Mottl, M.J., Davis, E.E., Fisher, A.T., and Slack, J.F. (Eds.), 1994. Proc. ODP, Sci. Results, 139: College Station, TX (Ocean Drilling Program).

${ }^{2}$ College of Oceanic and Atmospheric Sciences, Oregon State University, Corvallis, OR 97331, U.S.A
}

$\mathrm{m}$ below the seafloor (mbsf), and venting occurs at temperatures up to $265^{\circ} \mathrm{C}$ (Davis, Mottl, Fisher, et al., 1992).

Dissolved organic carbon (DOC) concentration was analyzed in interstitial water squeezed from sediments of Middle Valley and in surface- and near-bottom seawater collected on Alvin dive 2424 to understand the effect of hydrothermal activity on the water chemistry.

\section{EXPERIMENTAL PROCEDURES}

\section{Pore Water Sampling}

Interstitial waters were squeezed from whole-round sections of sediment cores 6 to $10 \mathrm{~cm}$ long, and from quarter-round sections up to $20 \mathrm{~cm}$ long (Davis, Mottl, Fisher, et al., 1992). Whole-rounds were cut from cores as soon as they arrived on deck. Quarter-rounds were taken from the working halves of cores several hours to days later only when additional samples were needed. Sediment from wholerounds was immediately extruded from the core liner, scraped with a Teflon-coated stainless steel spatula to remove the outer, contaminated layer, and placed in a titanium squeezer similar to the steel squeezer designed by Manheim and Sayles (1974). The squeezer and samples were handled with plastic gloves to avoid contamination. Sediments were squeezed in a Carver hydraulic press at pressures up to $2.8 \mathrm{MPa}$. Interstitial water was collected directly from the squeezer

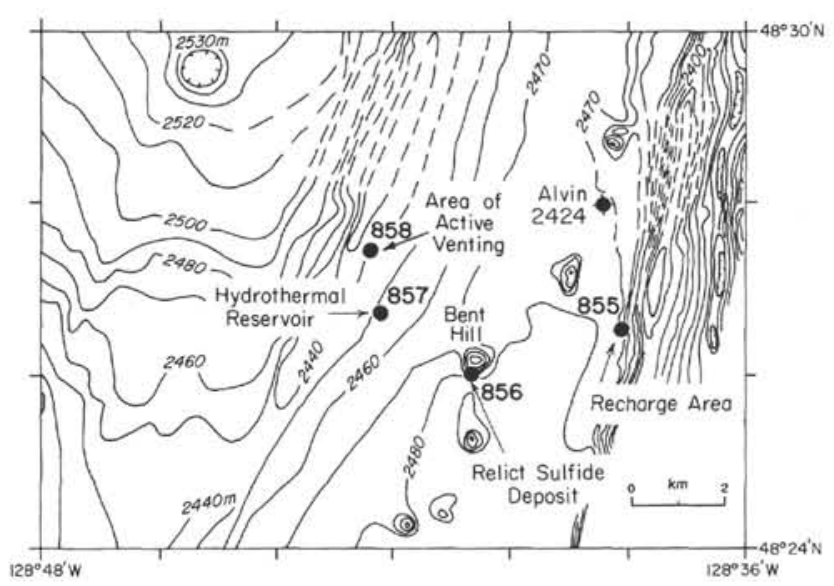

Fig. 1. Location map of Leg 139 drill sites in Middle Valley, northeast Pacific. 
into a 50-mL all-plastic syringe, from which the various aliquots for analysis were ejected through an on-line, $0.2-\mu \mathrm{m}$ polysulfone filter mounted in a Gelman "acrodisc" disposable filter holder. No attempt was made to equilibrate the sample with the in-situ temperature before squeezing (Davis, Mottl, Fisher, et al., 1992).

\section{DOC Analysis}

Nonvolatile DOC was analyzed by the high-temperature catalytic oxidation (HTCO) technique (Sugimura and Suzuki, 1988) by direct injection of each liquid sample. First, each water sample was acidified by adding $100 \mu \mathrm{L}$ of $10 \%$ phosphoric acid. The $\mathrm{CO}_{2}$ generated from the inorganic carbon species was expelled by bubbling with an oxygen stream for more than 5 minutes at a flow rate of $100 \mathrm{~mL} / \mathrm{min}$. A $60-\mu \mathrm{L}$ aliquot of the degassed water sample was injected by means of a microsyringe into the oxidation column (column conditions: $680^{\circ} \mathrm{C}$, oxygen atmosphere, flow rate $=100 \mathrm{~mL} / \mathrm{min}$ ). The nonvolatile fraction of the DOC in the water sample was quantitatively oxidized on the surface of the catalyst to $\mathrm{CO}_{2}$. The $\mathrm{CO}_{2}$ thus generated was dried by means of magnesium perchlorate before introduction into the gas analyzer. The quantitative determination of $\mathrm{CO}_{2}$ was carried out using an infrared detector in the gas analyzer. The HTCO system employed in this work was a Shimadzu Total Organic Carbon Analyzer, Model TOC-500.

\section{Standardization of Detector Response}

Sets of standards were prepared for the purpose of detector calibration. Each set of standards consisted of three solutions $(4.98,2.49$, $0.0 \mathrm{mg} \mathrm{C} / \mathrm{L}$ ) made by diluting a primary standard (potassium hydrogen phthalate, i.e., $\mathrm{PHP}, \mathrm{HKC}_{8} \mathrm{H}_{4} \mathrm{O}_{4}$, MW204: $0.2675 \mathrm{~g} / 250 \mathrm{~mL}$ ) in the proportions $1 / 10,1 / 20$, and 0 , respectively. Each of the solutions in a given standard set was run individually on the analyzer. Prior to analysis, $100 \mu \mathrm{L}$ of $10 \%$ phosphoric acid were added to the standard solutions and were purged with carrier gas for about $5 \mathrm{~min}$ to eliminate dissolved $\mathrm{CO}_{2}$. DOC analyses were carried out by repeated injections ( 3 or 5 times, $60 \mu \mathrm{L}$ each) of a given standard concentration until reproducible areas were obtained from the integrator.

\section{Sample Analysis}

First the $2.49 \mathrm{mg} \mathrm{C} / \mathrm{L}$ PHP standard was analyzed as an unknown. Repeated injections of this sample $(60 \mu \mathrm{L}$ each) were made until reproducible areas were obtained. The DOC content of this sample was calculated from the expression:

$$
\operatorname{DOC}(\mathrm{mg} \mathrm{C} / \mathrm{L})=m \times \text { area }+b,
$$

where area is the average of replicate sample injections, and $m$ and $b$ are the slope and intercept from the nondispersive infrared detector (NDIR) calibration curve established in the standardization procedure, respectively. The errors generally ranged from $5 \%-20 \%$ below the true values of the standards.

Then each sample was acidified, purged, and analyzed as described above. The DOC content of each sample was calculated as:

$$
\operatorname{DOC}(\mathrm{mg} \mathrm{C} / \mathrm{L})=m \times \text { area }
$$

It cannot be assumed that the "blank" for the pore water is the same as that for the treated water used to prepare the standard solutions. Therefore, the intercept, $b$, was excluded from the expression and the "blank" for the pore-water samples was considered to be zero. Whether this assumption is valid is an open question. The deionized water and the 4.98 and $2.49 \mathrm{mg}$ C/L PHP standards were rerun each time before a sample set was run, and the $2.49 \mathrm{mg} \mathrm{C} / \mathrm{L}$ standard was run every five samples to assure that the instrument remained in stable working order throughout the analyses.

\section{RESULTS AND DISCUSSION}

The DOC concentrations of Middle Valley surface seawater are about $0.5 \mathrm{mg} \mathrm{C} / \mathrm{L}$, which is in agreement with the typical range of DOC concentrations in seawater from shallow depths (less than 300 $\mathrm{m}$ ) of 0.4-0.8 mg C/L (Millero and Sohn, 1992) and 1.0-2.0 mg C/L (HTCO method, Tanoue, 1992). Seasonal variations in DOC occur primarily in shallow waters and are similar to those for primary productivity. At depths below a few hundred meters, the average DOC is $0.5 \mathrm{mg} \mathrm{C} / \mathrm{L}$ as determined by the ultraviolet irradiation method (Millero and Sohn, 1992) and 1 to $1.3 \mathrm{mg} \mathrm{C/L}$ by the HTCO method (Tanoue, 1992). In the aphotic oceanic water column, DOC concentrations are relatively uniform with depth. Recent HTCO measurements of dissolved organic carbon by Sugimura and Suzuki (1988) have revealed that their previously measured values may be low, although precisely how low is still under investigation (e.g., Ogawa and Ogura, 1992; Benner et al., 1993; Williams et al., 1993). The original data and measurements have been retracted (Suzuki, 1993). It should be emphasized that all the data reported here have been corrected for the procedural blank $(2.5 \mathrm{mg} \mathrm{C} / \mathrm{L})$ and thus the depth profiles for DOC are representative trends.

The DOC of near-bottom seawater collected on Alvin dive 2424 in Middle Valley is $3.7 \mathrm{mg} \mathrm{C} / \mathrm{L}$, which is significantly higher than that of surface seawater.

Except at Site 856, concentrations of DOC in interstitial waters of sediments are generally greater than those in the overlying water column, but the patterns and profiles are unique to each particular environment being investigated (see Bauer et al., 1991, for review). Krom and Westrich (1980) identified two patterns of pore water DOC concentrations based on the degree of sediment anoxia, with anoxic pore water containing up to 10 times more DOC than oxic pore water (see Bauer et al., 1991, for review). The UV photochemical oxidation analysis of DOC in pore waters from microbial mats and in waters of a hypersaline pond at Guerrero Negro, Baja California Sur, Mexico, showed that DOC concentrations in the water column over the mat displayed a diurnal pattern (Bauer et al., 1991). Pore water DOC ranged from 32 to $400 \mathrm{mg} \mathrm{C} / \mathrm{L}$ and exhibited a distinct concentration maximum in the mat surface layer (Bauer et al., 1991). Accurate information on both the quantitative and qualitative aspects of DOC in interstitial waters from oceanic sediments is lacking; therefore, further exploration of this topic is necessary.

Data for seawater and pore water from Sites $855,856,857$, and 858 are presented in Table 1 and Figure 2.

The DOC of pore water from Site 855 ranges from 2.1 to $19.4 \mathrm{mg}$ C/L (Fig. 2A). Profiles of DOC show a general decreasing trend with depth similar to the distributions of total carbon (TC), total inorganic carbon (TIC), total organic carbon (TOC), and free carbon dioxide in sediments in Holes 855A and 855C (Davis, Mottl, Fisher, et al., 1992). In Hole 855A, maximum DOC of the pore water is apparent at a depth of $13.6 \mathrm{mbsf}$ and is accompanied by high TOC and TIC (e.g., Fig. $3 \mathrm{~A}$ ), while in deeper intervals, the DOC remains approximately constant. In Hole $855 \mathrm{C}$, the DOC, TIC, and TOC exhibit similar trends. There is a DOC maximum at 24 mbsf and after a general decrease in DOC within the top $50 \mathrm{mbsf}$, at about $55 \mathrm{mbsf}$ there is an increase. These trends are also apparent in the TOC and TIC profiles (e.g., Fig. 3B; Davis, Mottl, Fisher, et al., 1992).

The DOC of pore water from Site 856 ranges from 0.1 to $10.5 \mathrm{mg}$ $\mathrm{C} / \mathrm{L}$ (Fig. 2B). DOC levels are generally low in both Holes $856 \mathrm{~A}$ and $856 \mathrm{~B}$, with the higher values occurring in deeper and surficial sections of Hole 856A. Hole 856B DOC levels are even lower than in Hole $856 \mathrm{~A}$ and both are significantly lower than DOC in the pore water of the recharge area at Site 855. The DOC profiles in the upper $60 \mathrm{mbsf}$ of the two holes are similar as are the TC and TOC trends of the sediments (e.g., Fig. 3C; Davis, Mottl, Fisher, et al., 1992). The DOC values for Site 856 are generally similar to those of seawater, which was also true for inorganic chemical species (Davis, Mottl, Fisher, et al., 1992). 
Table 1. Dissolved organic carbon concentration in pore water from Leg 139 and in ambient seawater of Middle Valley.

\begin{tabular}{|c|c|c|c|c|c|c|c|c|}
\hline $\begin{array}{l}\text { Core, section, } \\
\text { interval }(\mathrm{cm})\end{array}$ & $\begin{array}{l}\text { Depth } \\
\text { (mbsf) }\end{array}$ & $\begin{array}{c}\mathrm{DOC}^{\mathrm{a}} \\
(\mathrm{mg} \mathrm{C} / \mathrm{L})\end{array}$ & $\begin{array}{l}\text { Core, section, } \\
\text { interval }(\mathrm{cm})\end{array}$ & $\begin{array}{l}\text { Depth } \\
\text { (mbsf) }\end{array}$ & $\begin{array}{c}\mathrm{DOC}^{\mathrm{a}} \\
(\mathrm{mg} \mathrm{C} / \mathrm{L})\end{array}$ & $\begin{array}{l}\text { Core, section, } \\
\text { interval }(\mathrm{cm})\end{array}$ & $\begin{array}{l}\text { Depth } \\
\text { (mbsf) }\end{array}$ & $\begin{array}{c}\mathrm{DOC}^{\mathrm{a}} \\
(\mathrm{mg} \mathrm{C} / \mathrm{L})\end{array}$ \\
\hline $139-855 \mathrm{~A}-$ & & & $12 X-2,140-150$ & 84.6 & $4.4 \pm 0.8$ & $21 X-2,90-100$ & 171.1 & $6.3 \pm 1.6$ \\
\hline IR-I, 144-150 & 1.5 & $11.0 \pm 0.4$ & $13 \mathrm{X}-2,140-150$ & 94.1 & $2.3 \pm 0.1$ & $23 \mathrm{X}-1,22-31$ & 188.2 & $22.1 \pm 3.9$ \\
\hline IR-2, $144-150$ & 3.0 & $10.7 \pm 0.3$ & & & & $25 \mathrm{X}-1,0-10$ & 207.4 & $19.7 \pm 2.5$ \\
\hline $2 \mathrm{R}-1$ & $\sim 8.6$ & $8.5 \pm 0.3$ & $857 \mathrm{~A}-$ & & & $30 X-1,90-102$ & 256.6 & $14.3 \pm 2.3$ \\
\hline $2 \mathrm{R}-4,140-150$ & 13.6 & $19.4 \pm 1.5$ & $1 \mathrm{H}-1,144-150$ & 3.4 & $2.2 \pm 0.7$ & & & \\
\hline $3 R-2,140-150$ & 19.6 & $8.7 \pm 0.4$ & $2 \mathrm{H}-2,140-150$ & 14.4 & $4.8 \pm 0.2$ & 858B- & & \\
\hline $4 \mathrm{R}-3,140-150$ & 30.5 & $8.6 \pm 0.4$ & $3 \mathrm{P}-1,0-0$ & $\sim 21.4$ & $10.3 \pm 0.3$ & $1 \mathrm{H}-1,140-150$ & 1.5 & $6.5 \pm 0.9$ \\
\hline $5 \mathrm{R}-1,140-150$ & 37.0 & $6.3 \pm 0.5$ & $4 \mathrm{H}-4,140-150$ & 27.9 & $12.3 \pm 0.9$ & $1 \mathrm{H}-2,140-150$ & 3.0 & $0.1 \pm 0.1$ \\
\hline $6 \mathrm{R}-1,140-150$ & 47.0 & $11.3 \pm 1.2$ & $5 \mathrm{H}-4,140-150$ & 37.4 & $11.7 \pm 2.1$ & IH-4, $140-150$ & 6.0 & $4.7 \pm 0.5$ \\
\hline $7 \mathrm{R}-2,140-150$ & 58.1 & $7.7 \pm 0.7$ & $6 \mathrm{H}-4,140-150$ & 46.9 & $11.4 \pm 1.1$ & $2 \mathrm{H}-4,140-150$ & 13.2 & $12.0 \pm 3.5$ \\
\hline & & & $7 \mathrm{H}-1,0-0$ & 50.4 & $11.0 \pm 1.3$ & $2 \mathrm{H}-6,110-124$ & 15.9 & $31.1 \pm 1.9$ \\
\hline $855 B-$ & & & $8 \mathrm{H}-4,140-150$ & 65.9 & $8.0 \pm 0.5$ & $3 \mathrm{H}-1,3-13$ & 16.8 & $14.3 \pm 1.5$ \\
\hline $2 \mathrm{R}-\mathrm{t}, 140-150$ & 7.2 & $8.0 \pm 0.2$ & $9 \mathrm{H}-4,140-150$ & 75.4 & $5.6 \pm 0.4$ & $5 \mathrm{H}-3,140-150$ & 25.4 & $15.8 \pm 1.1$ \\
\hline $4 \mathrm{R}-3,140-150$ & 29.0 & $9.5 \pm 0.6$ & $10 \mathrm{H}-4,140-150$ & 84.9 & $8.6 \pm 1.3$ & & & \\
\hline & & & $13 \mathrm{X}-3,140-150$ & 106.0 & $5.7 \pm 1.3$ & 858C- & & \\
\hline $\begin{array}{l}855 C- \\
\text { IR-2, } 140-150\end{array}$ & 3.0 & & $857 \mathrm{~B}-$ & & & IH-1, $140-150$ & 1.5 & $\begin{array}{l}7.7 \pm 0.6 \\
24 \pm 02\end{array}$ \\
\hline IR-4, 144-150 & $\begin{array}{l}3.0 \\
6.0\end{array}$ & $14.9 \pm 0.8$ & $1 \mathrm{H}-2,144-150$ & 30 & $4.3+0.5$ & $\begin{array}{l}1 \mathrm{H}-2,140-150 \\
2 \mathrm{H}-2,144-150\end{array}$ & $\begin{array}{l}3.0 \\
6.5\end{array}$ & $\begin{array}{l}2.4 \pm 0.2 \\
6.5 \pm 0.2\end{array}$ \\
\hline $3 R-1,140-150$ & 19.2 & $9.1 \pm 0.7$ & $2 \mathrm{H}-2,140-150$ & 6.4 & $5.7 \pm 0.9$ & $2 \mathrm{H}-3,140-150$ & 8.0 & $20.3 \pm 5.3$ \\
\hline $3 R-4,140-150$ & 23.7 & $16.7 \pm 0.5$ & $3 \mathrm{H}-2,140-150$ & 24.0 & $16.9 \pm 1.1$ & $2 \mathrm{H}-5,144-150$ & 11.0 & $3.5 \pm 0.1$ \\
\hline $4 \mathrm{R}-3,140-150$ & 31.6 & $5.4 \pm 0.4$ & & & & $3 \mathrm{H}-3,144-150$ & 17.5 & $8.7 \pm 0.7$ \\
\hline $5 R-1,0-0$ & 36.6 & $7.9 \pm 0.9$ & $857 \mathrm{C}-$ & & & $3 \mathrm{H}-5,144-150$ & 20.5 & $10.1 \pm 0.5$ \\
\hline $6 \mathrm{R}-1,140-150$ & 48.0 & $6.6 \pm 0.7$ & IR-2, 144-150 & 3.0 & $9.4 \pm 1.0$ & $5 \mathrm{H}-4,140-150$ & 29.5 & $14.6 \pm 2.1$ \\
\hline $6 \mathrm{R}-6,140-150$ & 55.5 & $10.7 \pm 0.3$ & $2 \mathrm{R}-1,140-150$ & 58.0 & $4.4 \pm 0.2$ & $6 \mathrm{H}-3,140-150$ & 37.5 & $9.7 \pm 0.7$ \\
\hline $7 \mathrm{R}-2,140-150$ & 59.1 & $5.7 \pm 0.3$ & $3 R-2,140-150$ & 69.5 & $5.6 \pm 0.3$ & $7 \mathrm{H}-1,140-150$ & 43.0 & $7.0 \pm 0.2$ \\
\hline $7 R-5,140-150$ & 63.6 & $11.9 \pm 0.3$ & $6 \mathrm{R}-2,140-150$ & 89.2 & $14.4 \pm 2.1$ & $10 \mathrm{X}-\mathrm{CC}, 20-25$ & 49.8 & $11.3 \pm 1.7$ \\
\hline $8 R-1,70-75$ & 66.5 & $11.8 \pm 2.7$ & $9 \mathrm{R}-1,109-114$ & 115.6 & $21.5 \pm 3.2$ & $10 \mathrm{X}$-CC, $30-35$ & 54.0 & $75.7 \pm 5.1$ \\
\hline $9 \mathrm{R}-1,0-5$ & 75.2 & $10.8 \pm 0.4$ & $12 \mathrm{R}-2,0-10$ & 145.0 & $4.7 \pm 0.9$ & $11 X-1,5-15$ & 54.6 & $22.5 \pm 1.9$ \\
\hline $10 \mathrm{R}-2,0-10$ & 86.5 & $2.1 \pm 0.5$ & $13 \mathrm{R}-2,140-150$ & 156.1 & $5.1 \pm 0.6$ & $12 \mathrm{X}-1,131-145$ & 65.4 & $7.6 \pm 0.2$ \\
\hline $10 \mathrm{R}-3,140-150$ & 88.0 & $7.7 \pm 0.9$ & $14 \mathrm{R}-3,0-10$ & 165.8 & $11.8 \pm 1.5$ & $13 \mathrm{X}-1,41-46$ & 74.1 & $7.8 \pm 1.5$ \\
\hline $11 \mathrm{R}-2,0-10$ & 96.2 & $3.6 \pm 0.5$ & $15 R-3,0-10$ & 175.5 & $7.2 \pm 0.9$ & & & \\
\hline $855 \mathrm{D}$ & & & $17 \mathrm{R}-1,135-150$ & 193.4 & $8.1 \pm 0.4$ & 858D- & & $232+25$ \\
\hline $4 \mathrm{R}-1,45-50$ & 104.8 & $2.4 \pm 0.5$ & $\begin{array}{l}18 \mathrm{R}-2,0-15 \\
19 \mathrm{R}-2,0-15\end{array}$ & $\begin{array}{l}203.1 \\
2129\end{array}$ & $\begin{array}{r}10.2 \pm 1.4 \\
56+0.9\end{array}$ & $\begin{array}{l}1 \mathrm{H}-1,144-150 \\
1 \mathrm{H}-3,144-150\end{array}$ & $\begin{array}{l}1.5 \\
4.5\end{array}$ & $\begin{array}{r}23.2 \pm 2.5 \\
8.9 \pm 0.2\end{array}$ \\
\hline & & & $21 \mathrm{R}-2,135-150$ & 233.6 & $11.6 \pm 0.4$ & IH- $4.103-117$ & 5.6 & $20.9 \pm 2.1$ \\
\hline $856 \mathrm{~A}-$ & & & $24 \mathrm{R}-2,0-10$ & 260.8 & $8.8 \pm 1.1$ & $2 \mathrm{H}-2,2-16$ & 10.9 & $85.7 \pm 7.3$ \\
\hline $1 \mathrm{H}-2,0-6$ & 1.6 & $8.2 \pm 0.4$ & $26 \mathrm{R}-1,135-150$ & 276.0 & $11.0 \pm 1.1$ & $2 \mathrm{H}-3,144-150$ & 13.8 & $4.7 \pm 0.2$ \\
\hline $2 \mathrm{H}-1,140-150$ & 4.2 & $3.7 \pm 0.5$ & $27 \mathrm{R}-1,135-150$ & 285.6 & $57.7 \pm 2.9$ & $2 \mathrm{H}-5,144-150$ & 16.8 & $4.6 \pm 0.32$ \\
\hline $3 \mathrm{H}-1,143-150$ & 13.7 & $1.8 \pm 0.8$ & $28 \mathrm{R}-3,0-15$ & 296.9 & $10.2 \pm 2.4$ & $3 \mathrm{P}-1,0-13$ & 18.9 & $7.7 \pm 1.2$ \\
\hline $3 \mathrm{H}-5,143-150$ & 19.7 & $1.2 \pm 0.4$ & $30 \mathrm{R}-3,134-150$ & 317.6 & $5.6 \pm 1.2$ & $4 \mathrm{H}-2,144-150$ & 21.5 & $13.6 \pm 1.3$ \\
\hline $4 \mathrm{H}-1,140-150$ & 23.2 & $0.1 \pm 0.1$ & $33 \mathrm{R}-1,135-150$ & 333.9 & $81.3 \pm 3.3$ & $4 \mathrm{H}-6,134-149$ & 27.4 & $10.1 \pm 1.0$ \\
\hline $5 \mathrm{H}-6,140-150$ & 40.2 & $2.9 \pm 0.9$ & $36 \mathrm{R}-2,3-18$ & 347.8 & $23.8 \pm 4.1$ & & & \\
\hline $6 \mathrm{H}-5,140-150$ & 48.2 & $0.1 \pm 0.2$ & $40 \mathrm{R}-1,121-136$ & 366.7 & $16.1 \pm 2.3$ & $858 \mathrm{E}-$ & & \\
\hline $7 \mathrm{H}-5,140-150$ & 57.7 & $4.3 \pm 1.0$ & & & & IW, 24-25 & 34.0 & $11.5 \pm 0.8$ \\
\hline $8 \mathrm{H}-5,140-150$ & 67.2 & $1.0 \pm 0.6$ & $858 \mathrm{~A}-$ & & & & & \\
\hline $9 \mathrm{H}-5,140-150$ & 76.7 & $2.7 \pm 0.8$ & $1 \mathrm{H}-2,140-150$ & 3.0 & $14.2 \pm 0.6$ & $858 \mathrm{~F}-$ & & \\
\hline $10 X-1,140-150$ & 80.2 & $10.5 \pm 1.1$ & $2 \mathrm{H}-2,144-150$ & 5.4 & $8.3 \pm 0.7$ & $1 \mathrm{~W}-1,24-25$ & 26.2 & \\
\hline $11 \mathrm{X}-1,140-150$ & 87.7 & $0.7 \pm 0.2$ & $2 \mathrm{H}-3,144-150$ & 7.0 & $11.3 \pm 0.5$ & IW $-1,24-25$ & 26.2 & $10.8 \pm 0.7$ \\
\hline $13 \mathrm{X}-5,140-150$ & 112.8 & $6.6 \pm 0.7$ & $2 \mathrm{H}-5,144-150$ & 9.9 & $29.3 \pm 4.8$ & \multirow{6}{*}{\multicolumn{2}{|c|}{$\begin{array}{l}\text { Miscellaneous samples: } \\
\text { Middle Valley surface } \\
\text { seawater ( } 2 \text { samples) } \\
\text { Alvin Dive } 2424,8 \\
\text { August } 1991, \text { bottom } \\
\text { seawater }\end{array}$}} & \\
\hline & & & $3 \mathrm{H}-4,140-150$ & 17.9 & $3.8 \pm 0.7$ & & & $0.5 \pm 0.2$ \\
\hline $\begin{array}{l}856 \mathrm{~B}- \\
1 \mathrm{H}-1,144-150\end{array}$ & & & $4 \mathrm{H}-4,140-150$ & 27.4 & $27.7 \pm 4.6$ & & & $0.5 \pm 0.2$ \\
\hline $\begin{array}{l}1 \mathrm{H}-1,144-150 \\
2 \mathrm{H}-1,140-150\end{array}$ & $\begin{array}{l}1.5 \\
3.3\end{array}$ & $3.0 \pm 0.2$ & $5 \mathrm{H}-4,140-150$ & 36.9 & $20.7 \pm 0.3$ & & & $3.7 \pm 0.2$ \\
\hline $\begin{array}{l}2 \mathrm{H}-1,140-150 \\
3 \mathrm{H}-4,140-150\end{array}$ & $\begin{array}{r}3.3 \\
17.3\end{array}$ & $\begin{array}{l}2.5 \pm 0.4 \\
0.1 \pm 0.2\end{array}$ & $6 \mathrm{H}-2,140-150$ & 43.4 & $2.8 \pm 0.1$ & & & \\
\hline $4 \mathrm{H}-4,140-150$ & 26.8 & $\begin{array}{l}0.1 \pm 0.2 \\
0.7 \pm 0.3\end{array}$ & $\begin{array}{l}7 \mathrm{H}-2,140-150 \\
9 \mathrm{X}-2,0-10\end{array}$ & $\begin{array}{l}52.9 \\
64.1\end{array}$ & $\begin{array}{l}9.7 \pm 1.4 \\
3.4 \pm 0.5\end{array}$ & & & \\
\hline $5 \mathrm{H}-4,140-150$ & 36.3 & $0.4 \pm 1.5$ & $10 \mathrm{P}-1,0-8$ & 71.9 & $3.7 \pm 0.3$ & \multirow{7}{*}{\multicolumn{3}{|c|}{$\begin{array}{l}{ }^{a} \text { Standard deviation for } n=3 \text {; values cor- } \\
\text { rected for procedural blank. }\end{array}$}} \\
\hline $6 \mathrm{H}-4,140-150$ & 45.8 & $0.5 \pm 0.4$ & $10 \mathrm{P}-1$ & 72.4 & $3.5 \pm 0.1$ & & & \\
\hline $7 \mathrm{H}-3,140-150$ & 53.8 & $0.2 \pm 0.3$ & $11 X-1,43-53$ & 73.4 & $5.3 \pm 0.5$ & & & \\
\hline $8 \mathrm{H}-1,140-150$ & 60.3 & $0.1 \pm 0.3$ & $15 X-1.84-98$ & 111.5 & $6.1 \pm 0.2$ & & & \\
\hline $9 \mathrm{X}-1,140-150$ & 63.8 & $0.8 \pm 0.1$ & $16 \times-1,52-62$ & 120.9 & $10.8 \pm 0.6$ & & & \\
\hline $10 \mathrm{H}-1,140-150$ & 72.3 & $0.3 \pm 0.3$ & $18 X-1,137-147$ & 141.0 & $5.2 \pm 1.0$ & & & \\
\hline $11 X-3,140-150$ & 77.8 & $1.5 \pm 1.1$ & $20 \mathrm{X}-1,138-150$ & 160.5 & $5.4 \pm 0.2$ & & & \\
\hline
\end{tabular}

To evaluate the effects of hydrothermal alteration on sediments at Site 856 , depth profiles of elements highly affected by alteration in Holes $856 \mathrm{~A}$ and $856 \mathrm{~B}$ were compared with elemental profiles from Holes $855 \mathrm{~A}, 855 \mathrm{~B}$, and $855 \mathrm{C}$, which serve as reference holes. Below $60 \mathrm{mbsf}$, the DOC of the pore water increases, resembling the downhole chemical changes observed in Hole 856B below 65 mbsf (e.g., Figs. 3D-G; Davis, Mottl, Fisher, et al., 1992) (i.e., enrichment of $\mathrm{MnO}$ and $\mathrm{MgO}$ in the sediment, and in the depletion in $\mathrm{CaO}$ and $\mathrm{Sr}$ ). This chemical change could be applied to estimate the effects of hydrothermal activity on DOC. It is also known that the base of the massive sulfide deposit is a minimum of $60 \mathrm{~m}$ below the present level of turbidite fill in Middle Valley (Davis, Mottl, Fisher, et al., 1992).

The DOC of pore water from Site 857 varies from 2.2 to $81.3 \mathrm{mg}$ $\mathrm{C} / \mathrm{L}$ (Fig. 2C). In Hole $857 \mathrm{C}$, the values of DOC increase below 250 mbsf with two maxima, as is also observed with TOC (Fig. 3H, Davis, Mottl, Fisher, et al., 1992). Methane, ethane, and propane profiles increased exponentially with depth and temperature to about 300 mbsf, which is consistent with a thermogenic source for these hydro- carbons either in situ or at depth (Davis, Mottl, Fisher, et al., 1992). Therefore, we propose that a genetic relationship exists between the trends in the gases, TOC, and DOC.

The DOC of pore water from Site 858 varies from 0.1 to $85.7 \mathrm{mg}$ C/L (Fig. 2D). The DOC profiles of Holes $858 \mathrm{~A}$ to $858 \mathrm{D}$ have maxima at shallow depths and are not similar to the TOC and TIC trends vs. depth in the sediments of these holes (Davis, Mottl, Fisher, et al., 1992). Similar maxima are also observed in the concentrations of methane and ethane vs. depth in Hole 858C (Davis, Mottl, Fisher, et al., 1992).

In general, the concentrations of DOC in interstitial waters of Site 855 tend to decrease with depth. The DOC maxima at shallow depths of Site 858 are probably enrichments due to increased temperature. At Sites 856,857 , and 858 the increase in DOC at greater sub-bottom depths and the DOC maxima at shallow depths of Holes $858 \mathrm{~A}$ to $858 \mathrm{D}$ are probably also related to the higher temperatures. The relationship of elevated DOC in interstitial waters with hydrothermal activity below the seafloor can be interpreted as the release of polar 

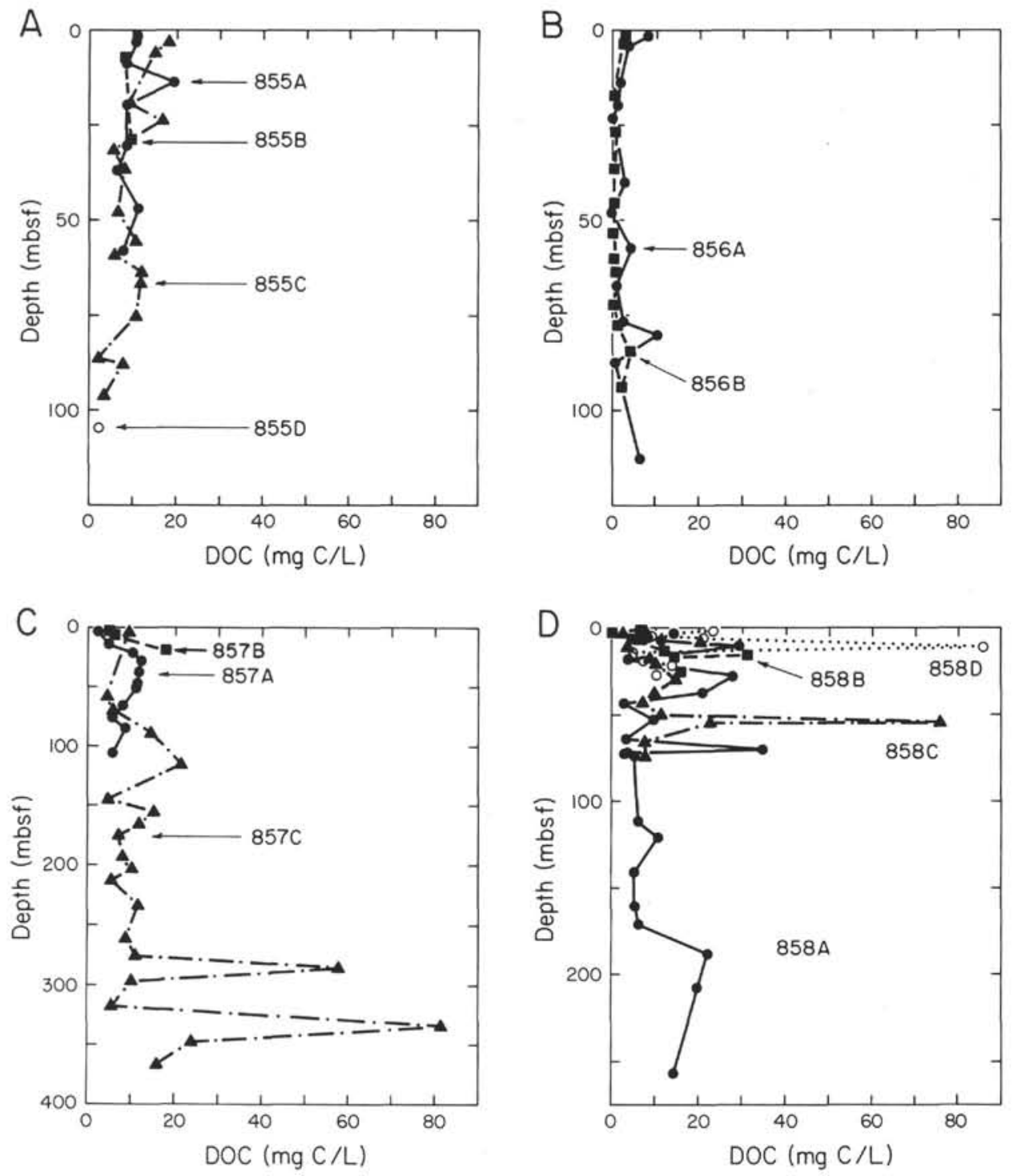

Fig. 2. Plots of dissolved organic carbon (DOC, mg C/L) in interstitial water vs. sub-bottom depth for the Leg 139 drill sites in Middle Valley. A. Site 855. B. Site 856. C. Site 857. D. Site 858.

organic compounds by thermal alteration of organic matter. Further statistical analysis is necessary for consideration of the geochemical significance.

A few problems still remain in obtaining accurate measurements of DOC of interstitial water samples. First, the effects of stress disturbance and different permeabilities of the sediments on the measurement of the interstitial water volume during pore-fluid sampling could introduce error (Davis, Mottl, Fisher, et al., 1992). Second, contamination by organic matter from various sources can be a problem. During drilling, seawater with lubricating oils and additives sometimes flows down into open fractures and cracks in the drilled sections. In one hole, water was observed flowing into the formation at a rate of more than 10,000 L/min (Davis, Mottl, Fisher, et al., 1992). Seawater contamination can be corrected for using the inorganic geochemical data from the pore waters. It would be useful to know the organic carbon concentration in the washing fluid utilized during drilling to assess the possibility of drilling fluid and oil lubricant contamination. In addition, adsorbed organic matter on glassware can contribute to contaminants. Thus, the cleaning of vials or ampoules by heating for 12 hours at $520^{\circ} \mathrm{C}$ could reduce contaminants to yield more accurate DOC results. Due to limitations aboard ship, glassware used in this study was cleaned using procedures that do not eliminate the possibility of contamination. The contributions of contaminants from drilling fluids and the handling procedure for the small volumes of interstitial water are also possible. Finally, DOC in natural marine waters has traditionally been difficult to study as a result of its complex nature and the dilute concentration at which it generally occurs (Bauer et al., 1991; Hedges and Bergamashi, 1992; Martin and Fitzwater, 1992; Ogawa and Ogura, 1992; Williams, 1992; Williams and Druffel, 1988; Benner et al., 1993; Williams et al., 1993; Suzuki, 1993). Problems and discrepancies also accompany the methods of DOC oxidation and the handling and analysis of large (for oceanic samples) or small (for pore water) sample volumes. The uncertainty in measuring DOC could also result from the differences in the magnitude of the blanks and how results are corrected for blanks (Ogawa and Ogura, 1992; Williams et al., 1993; Hedges et al., 1993).

\section{CONCLUSION}

High-temperature combustion oxidation measurements of DOC were determined on pore waters from Sites $855,856,857$, and 858 , as well as in overlying and near-bottom seawater of Middle Valley. 

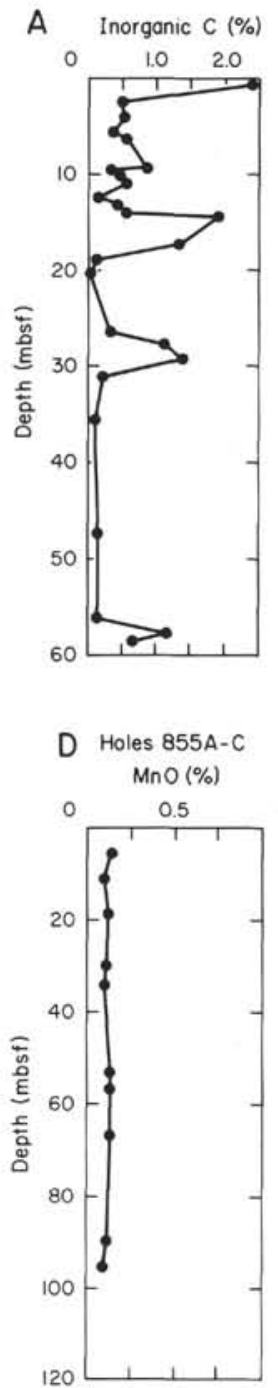

E Hole 8568

$\mathrm{MnO}(\%)$

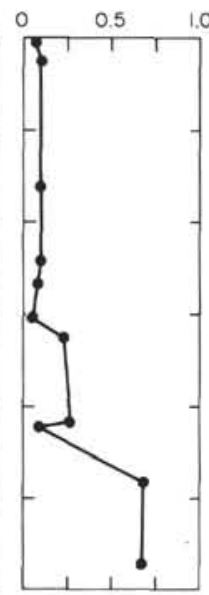

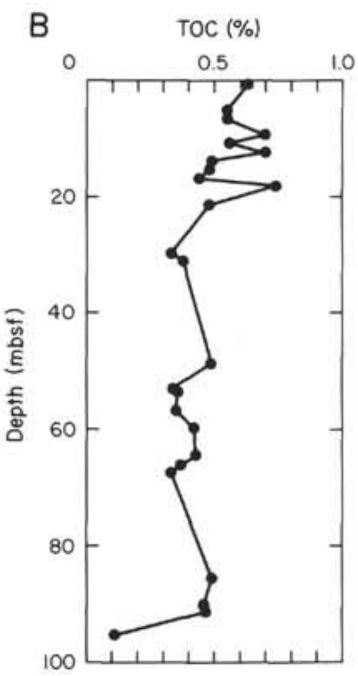

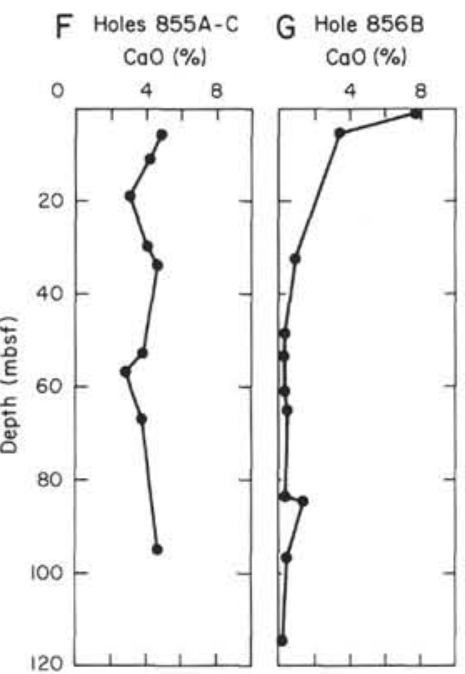

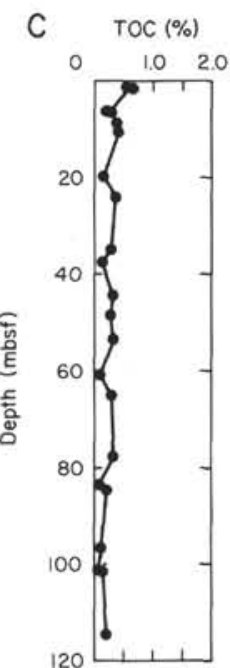

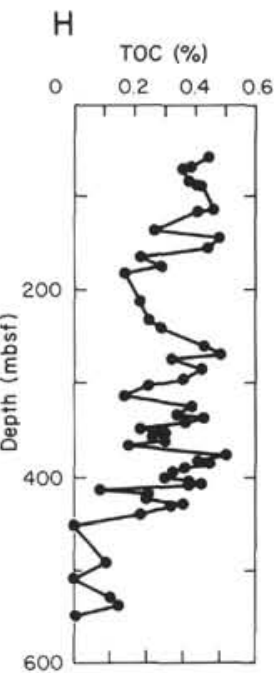

Fig. 3. Depth profiles of inorganic carbon, TOC (total organic carbon), $\mathrm{MnO}$, and $\mathrm{CaO}$ for comparisons with DOC profiles. A. Hole 855A. B. Hole 855C. C. Hole 856B. D. Holes 855A-C. E. Hole 856B. F. Holes 855A-C. G. Hole 856B. H. Hole 857C (Davis, Mottl, Fisher, et al., 1992).

The DOC values in the interstitial waters are generally greater (range 0.1 to $84 \mathrm{mg} \mathrm{C} / \mathrm{L})$ than those in the overlying water column $(0.5 \mathrm{mg}$ $\mathrm{C} / \mathrm{L}$ ). The near-bottom water had a DOC of $3.7 \mathrm{mg} \mathrm{C/L}$. The DOC profiles in the pore waters are similar to those of TOC, TC, and TIC. At Site 855 the concentrations of DOC in interstitial waters generally decrease with depth. At Sites 856 and 857 , besides the decreasing trend above, the DOC increases at greater depths as a consequence of the increasing temperature. The values of DOC correlate with the concentrations of sedimentary $\mathrm{MnO}$ and $\mathrm{MgO}$ in Hole $856 \mathrm{~B}$. The DOC values of Site 856 differ greatly from those of all the other sites and are similar to those of seawater, as is observed for other inorganic ionic species. The DOC depth profiles of Site 858 correspond with those of the volatile hydrocarbon gases, except that the maxima at shallow sub-bottom depths are probably related to high temperature effects.

\section{ACKNOWLEDGMENTS}

Financial support from the National Science Foundation and JOI, Inc. U.S. Science Support Program of the Ocean Drilling Program is gratefully acknowledged. The U.S. Science Program associated with the Ocean Drilling Program is sponsored by the National Science Foundation and the Joint Oceanographic Institutions, Inc. Any opin- ions, findings, and conclusions or recommendations expressed in this publication are those of the authors and do not necessarily reflect the views of the National Science Foundation, the Joint Oceanographic Institutions, Inc., or Texas A\&M University.

\section{REFERENCES*}

Bauer, J.E., Haddad, R.I., and Des Marais, D.J., 1991. Method for determining stable isotope ratios of dissolved organic carbon in interstitial and other natural marine waters. Mar. Chem., 33:335-351.

Benner, R., von Bodungen, B., Farrington, J., Hedges, J., Lee, C., Mantoura, F., Suzuki, Y., and Williams, P.M., 1993. Measurement of dissolved organic carbon and nitrogen in natural waters: workshop report. Mar: Chem., 41:5-10.

Davis, E.E., Mottl, M.J., Fisher, A.T., et al., 1992. Proc. ODP, Init. Repts., 139: College Station, TX (Ocean Drilling Program).

Hedges, J., Lee, C., and Wangersky, P., 1993. Comments from the editors on the Suzuki statement. Mar. Chem., 41:289-290.

Hedges, J.I., and Bergamashi, B.A., 1992. Seawater carbon measurement. Nature, 359:202.

\footnotetext{
- Abbreviations for names of organizations and publications in ODP reference lists follow the style given in Chemical Abstracts Service Source Index (published by American Chemical Society).
} 
Krom, M.D., and Westrich, J.T., 1980. Dissolved organic matter in pore waters of recent marine sediments: a review. In Biogéochimie de la Matière Organique à l'Interface Eau-Sediment Marin. Coll. Int. C.N.R.S., 103-111.

Manheim, F.T., and Sayles, F.L., 1974. Composition and origin of interstitial waters of marine sediments based on deep sea drill cores. In Goldberg, E.D. (Ed.), The Sea (Vol. 5): New York (Wiley Interscience), 527-568.

Martin, J.H., and Fitzwater, S.E., 1992. Dissolved organic carbon in the Atlantic, Southern and Pacific Oceans. Nature, 356:699-700.

Millero, F.J., and Sohn, M.L., 1992. Organic compounds. In Chemical Oceanography: Boca Raton, FL (CRC Press), 355-414.

Ogawa, H., and Ogura, N., 1992. Comparison of two methods for measuring dissolved organic carbon in seawater. Nature, 356:696-698.

Sugimura, Y., and Suzuki, Y., 1988. A high-temperature catalytic oxidation method for the determination of non-volatile dissolved organic carbon in seawater by direct injection of liquid samples. Mar. Chem., 24:105-131.

Suzuki, Y., 1993. On the measurement of DOC and DON in seawater. Mar. Chem., 41:287-288.
Tanoue, E., 1992. Vertical distribution of dissolved organic carbon in the North Pacific as determined by the high-temperature catalytic oxidation method. Earth Planet. Sci. Lett., 111:201-216.

Williams, P.J.leB., Bauer, J., Benner, R., Hegeman, J., Ittekot, V., Miller, A., Norrman, B., Suzuki, Y., Wangersky, P., and McCarthy, M., 1993. DOC subgroup report. Mar. Chem., 41:11-21.

Williams, P.M., 1992. Measurement of dissolved organic carbon and nitrogen in natural waters. Oceanography, 5:107-116.

Williams, P.M., and Druffel, E.R.M., 1988. Dissolved organic matter in the Ocean: comments on a controversy. Oceanography, 1:14-17.

Date of initial receipt: 9 February 1993

Date of acceptance: 30 July 1993

Ms 139SR-238 